\title{
Kinerja Pemeriksaan Hiv Pada layanan Konseling dan Tes Hiv Provinsi DKi Jakarta: Analisis Hasil Pemantapan Mutu EkSternal IMUNOlogi Tahun 2016
}

\author{
THE PERFORMANCE OF HIV TESTING AT THE HIV COUNSELING AND TESTING SERVICES IN \\ DKI JAKARTA PROVINCE: ANALYSIS OF THE RESULTS OF EXTERNAL QUALITY \\ ASSURANCE FOR IMMUNOLOGY YEAR 2016
}

\author{
${ }^{1}$ Eva Dian Kurniawati, ${ }^{2}$ Dumilah Ayuningtyas \\ ${ }^{1,2}$ Fakultas Kesehatan Masyarakat, Universitas Indonesia, Depok, Indonesia \\ email: eva.dian77@yahoo.com
}

\begin{abstract}
Human Immunodeficiency Virus (HIV) is still a public health problem in the world, even in Indonesia. One strategy for controlling HIV / AIDS is an extension of screening. In Indonesia, Rapid Diagnostic Test (RDT) is a-laboratory examination tool widely used for screening and diagnosing HIV. To- ensure the quality of the examination results, External Quality Assurance (EQA) coducted against each of the services that perform HIV tests. With a qualified laboratory examination, mortality, morbidity, and the spread of infectious diseases can be lowered. The purpose of this study was to describe the performance / quality of HIV testing of HIV Counseling and Testing (CT) services in Jakarta. This study using cross sectional study design, quantitative descriptive analysis method. The population in this study were HIV CT services in Jakarta, currently numbering 70 units. Samples were participants of EQA program for HIV, year of 2016 conducted by the Ministry of Health, as many as 32 units that met the inclusion criteria.
\end{abstract}

Keywords: Quality, External Quality Assurance, laboratory Performance, HIV tests, $R D T$

\begin{abstract}
Abstrak. Human Immunodeficiency Virus (HIV) sampai saat ini masih menjadi masalah kesehatan masyarakat di dunia, pun di Indonesia. Salah satu strategi pengendalian HIV/AIDS adalah perluasan skrining. Di Indonesia, Rapid diagnostic Test (RDT) menjadi alat pemeriksaan laboratorium yang banyak digunakan untuk skrining dan diagnostik HIV. Untuk menjaga mutu hasil pemeriksaannya, dilakukan Pemantapan Mutu Eksternal (PME) terhadap setiap layanan yang melakukan pemeriksaan HIV. Dengan pemeriksaan yang bermutu, mortalitas, morbiditas, dan penyebaran penyakit menular dapat diturunkan. Tujuan penelitian ini adalah untuk mendeskripsikan kinerja/mutu pemeriksaan HIV pada layanan Konseling dan Tes (KT) HIV di Provinsi DKI Jakarta. Penelitian ini menggunakan disain penelitian potong lintang, dengan metode analisis deskriptif kuantitatif. Populasi dalam penelitian ini adalah layanan KT HIV di Provinsi DKI Jakarta yang saat ini berjumlah 70 unit. Sampel penelitian adalah peserta PME bidang Imunologi parameter anti HIV, tahun 2016 yang dilaksanakan oleh kementerian Kesehatan, sebanyak 32 unit yang memenuhi kriteria inklusi.
\end{abstract}

Kata Kunci: Mutu, Pemantapan Mutu Eksternal, Kinerja laboratorium, Tes HIV, $R D T$ 


\section{Pendahuluan}

Human Immunodeficiency Virus (HIV), sampai saat ini masih menjadi masalah kesehatan masyarakat di dunia. Berdasarkan data Global Health Observatory (GHO) World Health Organization (2016), sejak awal epidemi, lebih dari 70 juta orang terinfeksi HIV dan sekitar 35 juta orang meninggal karena HIV/AIDS. Disebutkan pula bahwa pada akhir tahun 2015, terdapat kurang lebih 36,7 juta orang hidup dengan HIV dan 1,1 juta orang meninggal karena HIV/AIDS selama tahun 2015.

Di Indonesia, HIV/AIDS juga masih menjadi masalah kesehatan masyarakat. Sejak tahun 2005 Desember 2015, telah dilaporkan sebanyak 191.073 orang terinfeksi HIV di Indonesia. Jumlah kasus AIDS yang dilaporkan, tertinggi pada kelompok ibu rumah tangga (10.626), kemudian berturut-turut diikuti oleh tenaga non professional/karyawan (9.603), wiraswasta (9.439), petani/peternak/nelayan (3.674), buruh kasar (3.191), penjaja seks (2.578), PNS (1.819), dan anak sekolah/mahasiswa (1.764) (Kementerian Kesehatan, 2016).

Salah satu strategi yang diterapkan oleh Kementerian Kesehatan melalui Direktorat Jenderal Pengendalian Penyakit dan Penyehatan Lingkungan untuk mengendalikan penyakit HIV/AIDS, adalah perluasan skrining HIV/AIDS (Direktorat Jenderal Pengendalian Penyakit dan Penyehatan Lingkungan, 2015). Dalam 5 tahun akan dilakukan pemeriksaan/tes pada 15.000.000 sasaran, dengan target tahun 2015 sebanyak 7.000.000 tes. Target tahun 2016 hingga 2019 akan dilakukan secara bertahap untuk memenuhi target 15.000.000 tes. Sasaran tes ini adalah populasi ibu hamil, pasangan ODHA, masyarakat yang terinfeksi TB dan hepatitis, dan populasi kunci yaitu: pengguna napza suntik, Wanita Pekerja Seks (WPS) langsung dan tidak langsung, pelanggan/pasangan seks wanita pekerja seks (WPS), gay, waria, lelaki seks lelaki (LSL), dan warga binaan lapas/rutan (Direktorat Jenderal Pengendalian Penyakit dan Penyehata Lingkungan, 2015).

Tes HIV dilakukan di fasilitas yang memberikan pelayanan Konseling dan Tes (KT) HIV. Layanan KT HIV tersebut terintegrasi pada puskesmas, rumah sakit, klinik, lembaga pemasyarakatan, rumah tahanan, kantor kesehatan pelabuhan, dan Balai Kesehatan Paru Masyarakat. Sampai Maret 2015, terdapat 1.377 layanan KT HIV yang mampu melakukan layanan skrining dan diagnosis untuk mendukung program pengendalian HIV/AIDS (Direktorat Jenderal Pengendalian Penyakit dan Penyehatan Lingkungan, 2015). Layanan KT HIV ini tersebar di seluruh Indonesia dari Sabang sampai Merauke, dengan ketersediaan sumber daya fasilitas pelayanan yang berbedabeda.

Untuk dapat menghasilkan pemeriksaan yang bermutu, pada daerah dengan keterbatasan sumber daya, WHO telah merekomendasikan penggunaan alat tes cepat/rapid diagnostic test (RDT) yang bermutu untuk skrining dan diagnosis HIV. Di Indonesia, RDT banyak digunakan karena mudah digunakan, cepat mengeluarkan hasil, dan relatif murah harganya. Terkait dengan RDT ini, Mbaya (2012) mengatakan bahwa saat ini, RDT dapat digunakan untuk pemeriksaan skrining berbagai penyakit infeksi termasuk HIV, HBV, HCV, sifilis, dan malaria. Pada umumnya harga RDT murah, cara penyimpanannya mudah, dan waktu yang diperlukan untuk proses pemeriksaan spesimennya relatif singkat.

Tes HIV menggunakan RDT bermutu, dapat mengeluarkan hasil yang akurat, reliabel dan cepat. Hasil tes/pemeriksaan laboratorium yang bermutu sangat bermanfaat untuk kepentingan klinis maupun kesehatan masyarakat (WHO, 2011). Hasil tes HIV yang bermutu dapat menurunkan morbiditas, mortalitas, dan penyebaran infeksi HIV. Hal ini penting bagi ketahanan nasional bidang kesehatan. 
Dalam publikasinya, World Health Organization (2015) menyatakan bahwa untuk menjamin mutu hasil pemeriksaan HIV, semua laboratorium yang memberikan pelayanan pemeriksaan HIV harus mempunyai sistem manajemen mutu yang berfungsi dengan baik. Sistem manajemen mutu ini terdiri atas 12 sistem mutu utama, yaitu organisasi, sumber daya manusia, peralatan, pembelian dan persediaan, pengendalian proses, sistem informasi, dokumen dan pencatatan, manajemen kejadian, penilaian (pemantapan mutu eksternal dan supervisi), perbaikan proses, pelayanan pada pelanggan, fasilitas dan keselamatan kerja. Penerapan kedua belas sistem mutu tersebut dapat bervariasi antara satu laboratorium dengan laboratorium yang lain, namun prinsip dasarnya harus tetap dilaksanakan oleh semua laboratorium yang memberikan pelayanan pemeriksaan HIV.

Pemantapan Mutu Eksternal (PME) adalah suatu metode untuk memantau dan menilai kinerja laboratorium secara obyektif yang dilakukan oleh badan atau fasilitas di luar laboratorium itu sendiri (World Health Organization, 2011). Setiap laboratorium harus mengikuti pemantapan mutu eksternal secara rutin untuk semua jenis pemeriksaan. Hal ini penting untuk mendeteksi kesalahan dalam setiap prosedur yang dilakukan dan memaksimalkan akurasi hasil pemeriksaannya (Mbaya, 2013) dan (World Health Organization, 2011).

Dalam rangka peningkatan mutu pelayanan laboratorium kesehatan khususnya untuk mendukung program pengendalian HIV/AIDS, Direktorat Fasilitas Pelayanan Kesehatan (dulu bernama Direktorat Bina Pelayanan Penunjang Medik dan Sarana Kesehatan), sejak tahun 2010 telah menyelenggarakan kegiatan PME, berupa uji profisiensi. Peserta kegiatan ini adalah laboratorium fasilitas pelayanan kesehatan (fasyankes) yang melakukan Konseling dan Tes HIV. PME tahun 2016, diberikan pada 33 provinsi. Berdasarkan uraian di atas, maka penelitian ini dilakukan untuk mendeskripsikan gambaran kinerja/mutu pemeriksaan HIV pada layanan Konseling dan Tes (KT) HIV di Provinsi DKI Jakarta.

\section{Metode Penelitian}

Penelitian ini menggunakan disain penelitian potong lintang, dengan metode analisis deskriptif kuantitatif yaitu dengan menganalisis kinerja pemeriksaan HIV pada layanan KT HIV Provinsi DKI Jakarta. Populasi dalam penelitian ini adalah layanan KT HIV di Provinsi DKI Jakarta yang saat ini berjumlah 70 unit (Jakarta AIDS Information System, 2017), 33 diantaranya menjadi peserta PME bidang Imunologi, parameter anti HIV, yang diselenggarakan oleh Direktorat Fasilitas Pelayanan Kesehatan, Kementerian Kesehatan pada tahun 2016. Sampel adalah 32 unit layanan KT HIV peserta PME yang memenuhi kriteria inklusi. Data yang dianalisa merupakan data PME bidang Imunologi yang berasal dari Direktorat Fasilitas Pelayanan Kesehatan. Data yang dibutuhkan dari data PME tahun 2016 adalah data layanan, antara lain data nama fasilitas layanan KT HIV, jenis fasyankes, kode kepesertaan PME, reagen/RDT yang digunakan untuk melakukan tes HIV, hasil tes masing-masing RDT, ketepatan hasil, dan kesesuaian strategi. Kategori untuk tiap variabel mengacu pada hasil PME bidang Imunologi tahun 2016. Data yang tidak dapat dievaluasi karena tidak lengkap, tidak menggunakan reagen yang terdapat dalam daftar reagen yang memiliki izin edar dan sudah dievaluasi oleh Kementerian Kesehatan, dieksklusi.

Definisi hasil baik pada analisis ini adalah hasil pemeriksaan panel uji oleh peserta yang menunjukkan ketepatan hasil tes ketiga panel uji dibandingkan dengan rujukan dan kesesuaian strategi yang dijalankan oleh layanan pada pemeriksaan ketiga 
panel uji dengan strategi untuk diagnosis HIV menurut Permenkes nomor 15 tahun 2015.

Penilaian hasil PME parameter anti HIV meliputi 2 (dua) aspek yaitu ketepatan hasil pemeriksaan/tes dan kesesuaian strategi. Penilaian ketepatan hasil dilakukan dengan membandingkan hasil pemeriksaan yang dilakukan oleh peserta dengan hasil rujukan yang telah dikarakterisasi (diperiksa) oleh laboratorium rujukan nasional dengan metode ELISA dan western blot sebagai baku emas pemeriksaannya. Strategi yang digunakan sebagai rujukan adalah strategi 3 (strategi diagnostik) sesuai Permenkes nomor 15 tahun 2015 tentang Standar Pelayanan Laboraorium HIV dan Infeksi Oportunistik. Strategi 3 digunakan sebagai rujukan kesesuaian strategi karena peserta PME berasal dari layanan KT HIV yang melakukan pemeriksaan diagnostik sebagai salah satu tugas pokoknya.

Strategi pemeriksaan HIV disesuaikan dengan tujuan pemeriksaannya. Strategi 3 digunakan pada pemeriksaan dengan tujuan diagnostik. Strategi 2 digunakan pada pemeriksaan untuk tujuan surveilans. Dan Strategi 1 digunakan pada pemeriksaan skrining HIV, yang biasanya dilakukan pada pemeriksaan skrining darah donor. (Kemenkes, 2015)

Penilaian ketepatan hasil pemeriksaan dengan memperhitungkan kesimpulan hasil pemeriksaan setiap panel uji. Setiap panel uji diperiksa menggunakan strategi 3, sehingga setiap panel uji dapat diperiksa $1-3$ kali dengan menggunakan RDT yang berbeda sesuai dengan urutannya yang mengacu pada strategi 3. Setiap hasil peserta yang sesuai dengan rujukan diberi nilai 4 . Nilai 0 (nol) diberikan bila hasil pemeriksaan peserta tidak sesuai dengan rujukan. Dengan demikian jumlah nilai pemeriksaan (panel uji 1, panel uji 2, dan panel uji 3) maksimal 16 (enam belas) dan minimal 0 (nol). Hasil pemeriksaan dikategorikan tepat jika rata-rata nilai hasil pemeriksaan peserta adalah 4 , atau dengan kata lain semua hasil pemeriksaan peserta tepat sama dengan rujukan. Hasil dikatakan tidak tepat jika rata-rata nilai hasil pemeriksaan $<4$, atau dengan kata lain tidak semua hasil pemeriksaan peserta sama dengan rujukan.

Penilaian kesesuaian strategi meliputi kesesuaian alur pemeriksaan dan penempatan urutan penggunaan reagen/RDT yang pada pemeriksaan berdasarkan nilai sensitivitas dan spesifisitasnya. Acuan nilai sensitivitas dan spesifisitas RDT terdapat pada hasil evaluasi reagen/RDT HIV oleh laboratorium rujukan nasional Pemeriksaan Serologi HIV dan Infeksi Menular Seksual, serta Evaluasi/Pengujian Reagen HIV, Rumah Sakit Umum Pusat Nasional dr. Ciptomangunkusumo. (Kemenkes, 2015 dan Kemenkes, 2016). Penempatan urutan reagen/RDT HIV pada alur pemeriksaan HIV dengan strategi 3 adalah sebagai berikut:

1. Reagensia pertama harus memiliki sensitivitas tertinggi, $\geq 99 \%$.

2. Reagensia kedua memiliki spesifisitas $\geq 98 \%$ serta lebih tinggi dari reagensia pertama.

3. Reagensia ketiga memiliki spesifisitas $\geq 99 \%$ serta lebih tinggi dari reagensia kedua.

Strategi dinilai dengan memperhitungkan dua aspek penilaian, penempatan urutan RDT/reagen HIV pada pemeriksaan diagnosis dan alur pemeriksaannya. Kategori sesuai diberikan apabila kedua aspek tersebut dilakukan dengan benar dan mendapat nilai 5 (lima), sebaliknya bila salah satu atau kedua aspek penilaian salah maka pemeriksaan dinilai tidak sesuai dan mendapat skor 0 (nol). Penilaian kesesuaian strategi dengan memperhitungkan penerapan strategi 3 pada ketiga sampel panel yang diperiksa. Kesesuaian strategi dikategorikan sesuai bila pada pemeriksaan ketiga sampel panel nilai rata-ratanya 5, atau ketiga sampel panel diperiksa dengan menerapkan strategi 3. Kesesuaian strategi dikategorikan tidak sesuai bila pada pemeriksaan ketiga 
sampel panel nilai rata-ratanya $<5$, atau tidak semua dari ketiga sampel panel diperiksa dengan menerapkan strategi 3.

Penilaian hasil PME untuk setiap peserta dengan memperhitungkan aspek ketepatan hasil pemeriksaan dan kesesuaian strategi yang digunakan pada pemeriksaan panel uji dengan strategi diagnostik HIV. Hasil dikategorikan baik apabila hasil pemeriksaan ke tiga panel uji dan kesimpulan masing-masing mendapat nilai 4 dan kesesuaian strategi mendapat nilai rata-rata 5. Hasil PME tidak baik bila tidak memenuhi kriteria hasil baik.

\section{Hasil dan Pembahasan}

Jumlah penduduk Provinsi DKI Jakarta sebanyak 10.150.619. Jumlah kasus HIV sebanyak 1.114, dan 116 di antaranya sudah jatuh pada tingkat AIDS (Dinas Kesehatan provinsi DKI Jakarta, 2016). Untuk melayani penduduk yang ingin mengetahui status HIVnya, terdapat 70 unit layanan KT HIV di provinsi DKI Jakarta (Jakarta AIDS Information System, 2017).

Pada penelitian ini, sampel diambil dari data peserta program PME Bidang Imunologi tahun 2016 yang diselenggarakan oleh Direktorat Fasilitas Pelayanan Kesehatan Kemenkes. Tiga puluh dua layanan peserta program PME memenuhi kriteria inklusi. Sebagai kriteria inklusi adalah peserta yang mengikuti PME untuk parameter anti HIV dan melakukan pemeriksaan sampel panel uji profisiensi menggunakan reagen/RDT yang sudah memiliki izin edar dari Kemenkes dan telah dievaluasi oleh Laboratorium Rujukan Nasional untuk Evaluasi Reagen HIV.

RDT yang sudah dievaluasi oleh laboratorium rujukan nasional menggunakan spesimen Indonesia, memberikan nilai sensitivity dan specificity yang merepresentasikan kinerja RDT untuk memeriksa spesimen Indonesia. Sehingga gambaran hasil rujukan pemeriksaan sampel panel uji profisiensi akan sama jika dilakukan dengan mutu pemeriksaan yang sama oleh laboratorium layanan, dan hal ini digunakan sebagai dasar untuk menilai ketepatan hasil pemeriksaan. Selain itu, nilai sensitivity dan specificity RDT merupakan acuan untuk menentukan urutan penggunaannya pada pemeriksaan diagnostik HIV menggunakan strategi 3. Nilai sensitivity dan specificity RDT serta penempatan urutan penggunaan RDT ini menjadi dasar penilaian kesesuaian strategi. Oleh karena itu, pada penelitian ini peserta PME yang memeriksa sampel panel uji dengan RDT yang tidak sesuai persyaratan sebagaimana tersebut dalam Permenkes nomor 15 tahun 2015, dikeluarkan.

Hasil analisis menunjukkan bahwa semua (100\%) layanan KT HIV melaporkan hasil tes untuk ketiga sampel panel uji tepat sesuai dengan rujukan. Hal ini dapat disimpulkan bahwa ketepatan hasil pemeriksaan HIV layanan KT HIV Provinsi DKI Jakarta adalah 100\%. Ini berarti semua layanan KT HIV mampu memberikan mutu layanan yang baik terkait ketepatan hasil.

Sebanyak $27(84,4 \%)$ layanan KT HIV menunjukkan kesesuaian strateginya baik atau sesuai, sedangkan sisanya, sebanyak 5 (15,6\%), menunjukkan kesesuaian strateginya tidak baik atau tidak sesuai. Hal ini menunjukkan bahwa sebanyak $84,4 \%$ peserta PME menerapkan strategi 3 dalam pemeriksaan panel uji profisiensi yang diterimanya dan sebaliknya sebanyak 15,6\%. Dapat disimpulkan bahwa 15,6\% layanan KT HIV memberikan layanan pemeriksaan diagnostik HIV dengan mutu yang tidak baik terkait dengan kesesuaian strateginya. Namun begitu, capaian kinerja layanan KT HIV DKI Jakarta tersebut lebih besar dari capaian nasional yaitu sebesar $78 \%$ peserta PME hasilnya baik. 
Penilaian hasil PME meliputi penilaian ketepatan hasil dan kesesuaian strategi pemeriksaan. Sebanyak $84,4 \%$ peserta PME hasilnya baik. Artinya hasil pemeriksaan pada ketiga panel ujinya tepat dan menerapkan strategi 3 dalam pemeriksaannya. Capaian hasil baik provinsi DKI Jakarta sebesar 84,4\% layanan ini lebih tinggi dari pada capaian hasil baik secara nasional, yaitu sebesar $78 \%$ layanan. Sedangkan 15,6\% layanan KT HIV lainnya memperoleh hasil tidak baik. Ketidaksesuaian strategi dari 5 $(15,6 \%)$ layanan KT HIV berkontribusi terhadap 100\% jumlah peserta PME yang hasilnya tidak baik.

Ketidaksesuaian strategi dapat disebabkan oleh kurangnya pengetahuan teknisi laboratorium tentang strategi diagnostik HIV. Selain karena faktor pengetahuan teknisi laboratorium, ketidaksesuaian strategi juga dapat disebabkan oleh ketidaktersediaan RDT sesuai kebutuhan. Penyediaan RDT pertama untuk pemeriksaan diagnostik haruslah lebih banyak dari pada RDT kedua dan ketiga.

Penyediaan RDT untuk kebutuhan pemeriksaan perlu mempertimbangkan tujuan dan strategi pemeriksaan, serta prevalensi HIV pada daerah tersebut. Dalam perencanaan penyediaan kebutuhan laboratorium seperti: alat, reagen (RDT), dan bahan habis pakai, perlu metode perkiraan kebutuhan yang tepat. Oleh karena itu diperlukan data dari jumlah pemeriksaan tahun sebelumnya untuk dapat membuat perkiraan yang tepat (WHO, 2013).

Mutu layanan KT HIV khususnya layanan pemeriksaan laboratoriumnya merupakan faktor penentu diagnosis HIV. Dalam program pengendalian HIV, ketepatan diagnosis merupakan awal dari ketepatan tatalaksana penderita HIV. Diagnosis yang akurat, tepat, dan cepat menjadi faktor penting untuk menurunkan morbiditas dan mortalitas akibat jangkitan HIV. Selain morbiditas dan mortalitas, ketepatan diagnosis juga dapat menurunkan angka penularan HIV.

Mutu pemeriksaan skrining dan diagnostik HIV yang tidak baik dapat mengakibatkan meningkatnya kesalahan hasil skrining dan diagnosis. Tidak terdeteksinya pengidap HIV sebagai HIV positif, berpotensi menularkan HIV lebih luas, meningkatkan morbiditas dan mortalitas akibat tidak segera tertanganiny pengidap HIV positif. Sebaliknya jika seorang teerdeteksi sebagai penderita HIV dari hasil pemeriksaan laboratorium, padahal sesungguhnya tidak ada virus HIV di tubuhnya, akan merugikan orang tersebut secara moril dan materil. Kerugian tersebut dapat berupa jatuhnya mental, stigma negatif, efek samping pengobatan, dan kerugian materil yang disebabkan pengobatan yang seharusnya tidak diterimanya.

\section{Kesimpulan}

Kinerja layanan KT HIV di provinsi DKI Jakarta sebagian besar adalah baik, Hal ini dapat dilihat dari hasil PME bidang Imunologi, parameter anti HIV yang diselenggarakan Direktorat Fasilitas Pelayanan Kesehatan tahun 2016 yaitu sebesar $84,4 \%$ layanan KT HIV hasilnya baik. Capaian DKI Jakarta ini lebih besar dari nasional yaitu sebesar $78 \%$ peserta PME hasilnya baik. Sedangkan 15,6\% layanan KT HIV mempunyai kinerja pemeriksaan HIV yang tidak baik. Dan $100 \%$ dari layanan KT HIV dengan hasil PME tidak baik tersebut karena ketidaksesuaian strategi pemeriksaan yang dilaksanakan pada pemeriksaan diagnosis HIV dengan strategi standar sesuai Permenkes nomor 15 tahun 2015. 


\section{Daftar pustaka}

World Health Organization. (2016). Global Health Observatory Data. Geneva http://www.who.int/hiv/data/epi_core_2016.png

Kementerian Kesehatan. (2016). Menkes Canangkan Gerakan Tes HIV untuk Tingkatkan Pencegahan dan Pengendalian HIV/AIDS. Jakarta

http://www.depkes.go.id/article/view/16120200001/menkes-canangkan-gerakan-tes-

hiv-untuk-tingkatkan-pencegahan-dan-pengendalian-hiv-aids-

.html\#sthash.oUr097iz.dpuf

Ditjen Pengendalian Penyakit dan Penyehatan Lingkungan. (2015). Rencana Aksi

Program Pengendalian Penyakit dan Penyehatan Lingkungan Tahun 2015-2019.

Jakarta

http://www.depkes.go.id/resources/download/LAKIP\%20ROREN/1\%20perencanaan\%

20kinerja/Rencana\%20Aksi\%20Program\%20PPPL.pdf

Mbaya. (2013). Use of quality rapid diagnostic testing for safe blood transfusion in resource-limited settings, Cameroon

World Health Organization. (2015). Post-Market Surveillance of in Vitro Diagnostics.

Geneva

World Health Organization. (2011). Laboratory Quality Management System: hand book, Geneva

http://apps.who.int/iris/bitstream/10665/44665/1/9789241548274_eng.pdf

World Health Organization. (2015). Hiv Assays Laboratory Performance And Other

Operational Characteristics Rapid Diagnostic Tests (Combined Detection Of Hiv-

1/2 Antibodies And Discriminatory Detection Of Hiv-1 And Hiv-2 Antibodies), Report 18.Geneva

http://www.who.int/diagnostics_laboratory/publications/15032_hiv_assay_report18.pdf ?ua $=1$

Kementerian Kesehatan RI. (2016). Indonesia Tingkatkan Komitmen Penanggulangan HIV-AIDS. Jakarta

Kementerian Kesehatan RI. (2015). Permenkes nomor 15 tahun 2015 tentang Standar Pelayanan Laboratorium Pemeriksa HIV dan Infeksi Oportunistik. Jakarta

Jakarta AIDS Information System. (2017). Daftar Layanan HIV \& AIDS di Dki Jakarta Tahun 2015. Jakarta

http://jakartaaids.org/jumlah-layanan-hiv-aids/ (Diunduh pada tanggal 31 Mei 2017, pukul 08.00)

Kementerian Kesehata RI. (2015). Daftar Evaluasi Reagen HIV. Jakarta

Dinas Kesehatan Provinsi DKI Jakarta. (2016). Profil Kesehatan Provinsi DKI Jakarta

Tahun 2015. Jakarta 